REGARDS

SUR L'ECONOMIE ALLEMANDE

BULLETIN ECONOMIQUE DU CIRAC
Regards sur l'économie allemande

Bulletin économique du CIRAC

$92 \mid 2009$

Varia

\title{
Droit de la concurrence
}

WIEDEMANN Gerhard (ed), Handbuch des Kartellrechts

\section{OpenEdition}

\section{Journals}

Édition électronique

URL : http://journals.openedition.org/rea/3777

DOI : $10.4000 /$ rea. 3777

ISBN : 978-2-8218-0880-5

ISSN : 1965-0787

\section{Éditeur}

CIRAC

Édition imprimée

Date de publication : 1 juillet 2009

ISSN : 1156-8992

Référence électronique

"Droit de la concurrence », Regards sur l'économie allemande [En ligne], 92 I juillet 2009, mis en ligne le 28 août 2009, consulté le 22 septembre 2020. URL : http://journals.openedition.org/rea/3777 ; DOI : https://doi.org/10.4000/rea.3777

Ce document a été généré automatiquement le 22 septembre 2020

(C) CIRAC 


\section{Droit de la concurrence}

WIEDEMANN Gerhard (ed), Handbuch des Kartellrechts

\section{RÉFÉRENCE}

WIEDEMANN Gerhard (ed), Handbuch des Kartellrechts, $2^{e}$ édition, Verlag C. H. Beck, Munich, 2008, $2172 \mathrm{p}$.

1 Paru pour la première fois en 1999, ce manuel conçu par des praticiens pour des praticiens propose de rassembler en un seul et même volume les grandes questions relatives au droit de la concurrence. Cette seconde édition, dirigée par G. WIEDEMANN, avocat et professeur honoraire à l'Université de Rostock, tient compte des évolutions juridiques de ces neuf dernières années, comme par exemple le règlement de procédure du droit européen de la concurrence $\left(n^{\circ} 1 / 2003\right)$, celui exonérant les ententes verticales $\left(n^{\circ} 2790 / 1999\right)$ ou les ententes dans le cadre de transferts de technologies $\left(n^{\circ} 772 / 2004\right)$, les modifications du règlement européen relatif au contrôle des fusions suite à l'amendement de $2004\left(\mathrm{n}^{\circ} 139 / 2004\right)$, le $7^{\mathrm{e}}$ amendement de la loi fédérale des cartels GWB (2005) ou encore celui du 21 décembre 2007 portant sur les abus de prix. $(\mathrm{sh})$ 